This article is licensed under the Creative Commons Attribution-NonCommercial 4.0 International License (CC BY-NC) (http://www.karger.com/Services/OpenAccessLicense). Usage and distribution for commercial purposes requires written permission.

\title{
Epinephrine in the Prevention of Post-Endoscopic Retrograde Cholangiopancreatography Pancreatitis: A Preliminary Study
}

\author{
Behzad Hatami $^{\mathrm{a}}$ Seyed Mohammad Hossein Kashfi ${ }^{\mathrm{a}}$ \\ Mohammad Abbasinazarib Ehsan Nazemalhosseini Mojarad ${ }^{\mathrm{a}}$ \\ Mohammad Amin Pourhoseingholi ${ }^{a} \quad$ Mohammad Reza Zali ${ }^{a}$ \\ Amir Houshang Mohammad Alizadeh ${ }^{\mathrm{a}}$ \\ ${ }^{a}$ Gastroenterology and Liver Diseases Research Center, Research Institute for \\ Gastroenterology and Liver Diseases, Shahid Beheshti University of Medical Sciences, \\ Tehran, Iran; ${ }^{b}$ Department of Clinical Pharmacy, School of Pharmacy, Shahid Beheshti \\ University of Medical Sciences, Tehran, Iran
}

\section{Keywords}

Endoscopic retrograde cholangiopancreatography · Post-endoscopic retrograde cholangiopancreatography pancreatitis

\begin{abstract}
Background: Acute pancreatitis is the most common complication of endoscopic retrograde cholangiopancreatography (ERCP). The incidence of post-ERCP pancreatitis (PEP) ranges between 15 and 20\% among patients at high risk of developing PEP. The efficacy of indomethacin administration in the prevention of PEP is rather debatable. In the present randomized trial study, we evaluated whether or not the combination of indomethacin and epinephrine in comparison to the single administration of indomethacin differs in the pathogenesis
\end{abstract}




\section{Case Reports in Gastroenterology}

Case Rep Gastroenterol 2018;12:125-136

(C) 2018 The Author(s). Published by S. Karger AG, Base www.karger.com/crg

Hatami et al.: Epinephrine in the Prevention of Post-Endoscopic Retrograde

Cholangiopancreatography Pancreatitis: A Preliminary Study

and prevention of post-ERCP pancreatitis. Patients and Methods: One hundred and ninetytwo patients were randomized in a double-blinded manner into 3 groups: the epinephrine group (group A), the indomethacin group (group B), and the combined epinephrine and indomethacin group (group C). After the procedure, patients were evaluated for the PEP development. Results: During the procedure, 66 patients were randomized to the epinephrine group (group A), 68 cases to the indomethacin group (group B), and 58 individuals to the indomethacin-epinephrine group (group C). The mean age of patients in the epinephrine group was $59.59 \pm 15.680$ years, in the indomethacin group it was $58.06 \pm 17.125$ years, and in the combination group it was $59.62 \pm 15.369$ years. In the present study, we did not observe a significant difference between the 3 groups in sex, age, pre-ERCP amylase, lipase, and patient and procedure risk factors including pancreatic duct (PD) dilation $(p=0.404)$, PD cannulation $(p=0.329)$, and difficult cannulation $(p=0.076)$ among others. PEP developed in 7 of the 192 individuals (3.6\%), 6 PEP cases occurred in the indomethacin group and 1 in the epinephrine group $(p=0.016)$. Univariate analysis of risk factors for PEP in patients with and without pancreatitis revealed no significant difference between the pancreatitis group and the non-pancreatitis group. Conclusion: In comparison to the administration of indomethacin alone, a single application of epinephrine and the combination of epinephrine and indomethacin seem to be effective in reducing the cases of PEP. A further randomized clinical trial with a larger sample size is required to confirm the efficacy of our medication in the prevention of pancreatitis after ERCP.

(C) 2018 The Author(s)

Published by S. Karger AG, Basel

\section{Introduction}

Acute pancreatitis is the most common complication of endoscopic retrograde cholangiopancreatography (ERCP) [1]. The incidence of post-ERCP pancreatitis (PEP) ranges between 15 and $20 \%$ among patients at high risk of developing PEP $[2,3]$. The pathogenesis of acute pancreatitis is not clearly identified. It has been reported that an aberrant calcium signaling pathway and reactive oxygen species might lead to autodigestion of the pancreas by its own proteases [4]. Therefore, several studies were carried out to identify the mechanisms underlying PEP in high-risk patients. However, papillary edema has been the focal point $[5,6]$. Many different approaches have been applied in order to reduce the risk of PEP in patients and several pharmacologic agents have been examined for their effect on reducing the incidence rate and severity of PEP. Among these prophylactic agents, nonsteroidal anti-inflammatory drugs (NSAIDs), especially indomethacin and diclofenac, have previously been evaluated in several randomized controlled trials [7, 8]. Via inhibiting phospholipase A2 (PLA2), NSAIDs play a significant role in the prevention of acute pancreatitis [9]. Other pharmacologic agents have also been evaluated for their prophylactic effects on PEP including protease inhibitors such as gabexate, ulinastatin, and nafamostat mesylate [10-12] and vasoactive mediators including lidocaine, nifedipine, epinephrine, and glyceryltrinitrate [5, 13-16]. The efficacy of indomethacin in the prevention of pancreatitis after ERCP is rather debatable with some studies supporting its significant role in reducing the severity and incidence of pancreatitis [7, 17-19], while others indicated the lack of any improvement in the case of indomethacin administration [20-22]. On the other hand, topical pharmacologic 


\section{Case Reports in Gastroenterology}

Case Rep Gastroenterol 2018;12:125-136

DOI: $10.1159 / 000479494$

(c) 2018 The Author(s). Published by S. Karger AG, Base www.karger.com/crg

Hatami et al.: Epinephrine in the Prevention of Post-Endoscopic Retrograde

Cholangiopancreatography Pancreatitis: A Preliminary Study

agents have had some benefits over other interventions. In this regard, the role of local administration of epinephrine on reducing the incidence and severity of PEP has been reported in several studies $[5,15,23]$. The objective of this prospective randomized trial study was to evaluate whether or not the combination of indomethacin and epinephrine in comparison to the single administration of indomethacin differs in the pathogenesis and prevention of PEP.

\section{Patients and Methods}

This study was designed as a randomized, prospective, double-blind trial. Informed consent was obtained from all individuals and the research proposal was approved by the ethics committee of the Gastroenterology and Liver Diseases Research Center, Research Institute for Gastroenterology and Liver Diseases, Shahid Beheshti University of Medical Sciences, Tehran, Iran. From April 2013 to October 2014, patients who referred to the Endoscopy Unit of Taleghani Hospital for ERCP were recruited into this prospective study. A total of 293 patients underwent therapeutic ERCP; however, 101 patients were excluded from the study according to our exclusion criteria. Ultimately, 192 patients (98 male and 94 female) were included in this study. The age of the individuals ranged between 18 and 89 years. The mean age of patients was $59.06 \pm 16.049$ years. The demographic characteristics of the patients in this study are shown in Table 1. Exclusion criteria were as follows: the pancreatic duct (PD) stent placement, history of acute pancreatitis, age under 18 years, prior endoscopic sphincterotomy, chronic pancreatitis with an acute exacerbation, an elevated serum amylase or lipase level (more than the upper normal limit: $>100$ and $>60$ IU/L, respectively), and an allergy to epinephrine. Patients who fulfilled the inclusion criteria were randomized into study groups. High-risk patients were defined as follows: suspected sphincter of Oddi dysfunction (SOD), precut biliary sphincterotomy, PD cannulation (at least once), endoscopic balloon dilation (after sphincterotomy), and the presence of more than two of the other risk factors including female sex, age $<40$ years, nondilated common bile duct (CBD), normal bilirubin, and difficult cannulation [24].

\section{Study Design}

The patients were randomized in a double-blinded manner into 3 groups: the epinephrine group (group A), the indomethacin group (group B), and the combined epinephrine and indomethacin group (group C). Randomization and administration of epinephrine or indomethacin were done by personnel who were not involved in the endoscopic procedure. The allocation was done using the random number generated by a computer. Each patient had a number corresponding to these random numbers and they were included in their specific group by this pattern. During the procedure, patients randomly received a spray of $10 \mathrm{ml}$ epinephrine (diluted to $1 / 10,000$ in saline) on the major papilla (immediately after ERCP) and a suppository placebo tablet (group A) or a suppository containing $100 \mathrm{mg}$ of indomethacin (immediately after procedure) and normal saline solution sprayed on the major papilla (group B), or a combination of epinephrine on the major papilla and administration of 100 $\mathrm{mg}$ of indomethacin (group $\mathrm{C}$ ). After the procedure, patients were evaluated for the PEP development. 


\section{Case Reports in Gastroenterology}

Case Rep Gastroenterol 2018:12:125-136

DOI: $10.1159 / 000479494$

(c) 2018 The Author(s). Published by S. Karger AG, Basel www.karger.com/crg

Hatami et al.: Epinephrine in the Prevention of Post-Endoscopic Retrograde

Cholangiopancreatography Pancreatitis: A Preliminary Study

Definition of PEP

Serum amylase and lipase concentrations were measured and recorded before ERCP, 4 and $24 \mathrm{~h}$ after ERCP as indicated in Table 1. PEP was defined as an elevation of serum amylase levels more than threefold of the upper normal limit associated with at least two clinical symptoms including abdominal pain or tenderness, backache, nausea, and vomiting. The normal upper limit of serum amylase is $100 \mathrm{IU} / \mathrm{L}$. The severity of PEP was classified as mild, moderate, or severe according to consensus classification [25]. We included patients with suspected SOD and we did not use manometry for the definition of SOD. Patients were prospectively evaluated for the occurrence of PEP between the groups.

\section{Statistical Analysis}

All quantitative variables were indicated as mean \pm SD. The 3 groups were evaluated for statistical analysis. For the continuous variables, the analysis of variance was performed and the comparison between the groups was also assessed by the $\chi^{2}$ test or the Fisher exact test. A $p$ value of less than 0.05 was considered a statistical significance between the groups. According to Sotoudehmanesh et al. [7], in the case of any significant effect, relative risk reduction (RRR), absolute risk reduction (ARR), and number needed to treat (NNT) were computed with their $95 \%$ CI.

\section{Results}

During 2013-2014, 293 patients underwent therapeutic ERCP; however, 101 patients were excluded from the study according to our exclusion criteria: prior endoscopic sphincterotomy ( $n=6-8)$, PD stent placement ( $n=9)$, history of acute pancreatitis $(n=7)$, age under 18 years $(n=6)$, chronic pancreatitis with an acute exacerbation $(n=5)$, an elevated serum amylase or lipase level (more than the upper normal limit: $>100$ and $>60$ IU/L, respectively) $(n=4)$, and an allergy to epinephrine $(n=2)$. Ultimately, 192 patients were recruited. During the ERCP, among 192 patients, 66 were randomized to the epinephrine group (group A), 68 to the indomethacin group (group B), and 58 to the combined indomethacin-epinephrine group (group C) (Fig. 1). The mean age of patients in the epinephrine group was $59.59 \pm 15.680$ years, in the indomethacin group it was $58.06 \pm 17.125$ years, and in the combination group it was $59.62 \pm 15.369$ years.

\section{Procedure Outcomes}

In the present study, we did not observe a significant difference between the 3 groups in sex, age, pre-ERCP amylase, lipase, PD dilation $(p=0.404)$, PD cannulation $(p=0.329)$, difficult cannulation ( $p=0.076)$, sphincterotomy ( $p=0.421)$, needle knife precut $(p=0.610)$, PD injection ( $p=0.687)$, balloon dilation of sphincter of Oddi $(p=0.533)$, biliary stricture $(p=$ $0.712)$, biliary duct tumor ( $p=0.389)$, peri-ampullary diverticulum $(p=0.872)$, and suspected SOD ( $p=0.808)$. In this study, PEP developed in 7 of the 192 individuals $(3.6 \%), 6$ PEP occurred in the indomethacin group and 1 case in the epinephrine group. However, none of the patients in the combination group (epinephrine and indomethacin) developed pancreatitis $(p=0.016)$ (Table 2). Univariate analysis of risk factors for PEP in patients with and without pancreatitis is presented in Table 3. In this study, there was no death due to pancreatitis 


\section{Case Reports in Gastroenterology} \begin{tabular}{l|l}
\hline Case Rep Gastroenterol 2018;12:125-136 \\
\hline DOI: 10.1159/000479494 & $\begin{array}{l}\text { @ 2018 The Author(s). Published by S. Karger AG, Basel } \\
\text { www.karger.com/crg }\end{array}$ \\
\hline
\end{tabular}

Hatami et al.: Epinephrine in the Prevention of Post-Endoscopic Retrograde

Cholangiopancreatography Pancreatitis: A Preliminary Study

in the related patients. There was no significant difference between the pancreatitis group and the non-pancreatitis group according to PD dilation (0.739), suspected SOD (0.739), cholecystectomy (0.581), CBD stone (0.355), difficult cannulation (0.343), sphincterotomy (0.134), needle knife precut (0.403), PD cannulation (0.368), PD injection (0.798), balloon dilation of the sphincter of Oddi (0.419), CBD dilation (0.571), biliary stricture (0.330), biliary duct tumor (0.462), and peri-ampullary diverticulum (0.571) (Table 3).

\section{Discussion}

Several pharmacologic components and endoscopic interventions have been utilized in order to prevent PEP. These are including anti-secretory agents, sphincter relaxants, antiinflammatory agents, antioxidants, and protease inhibitors among others. Among these agents, however, indomethacin as a safe, inexpensive, available, easy-to-administer agent, which is associated with few side effects, has been shown to be effective in reducing the severity of PEP in previous studies [17-19, 26, 27], whereas a number of other studies indicated a null effect of indomethacin in preventing PEP $[20-22,28]$. On the other hand, topical application of epinephrine as a vasoactive mediator has been reported to reduce PEP via decreasing the papillary edema. Lately, combination therapy has been emerged as an efficacious approach in preventing PEP [29-31]. In this prospective randomized trial study, we evaluated whether or not the combination of indomethacin and epinephrine differs in the pathogenesis and prevention of PEP. In our study, we found that among 68 patients in the indomethacin group, 6 individuals developed pancreatitis; however, in the epinephrine group only 1 patient developed pancreatitis (1/66). Among the 58 patients who received the combination medication, none developed pancreatitis. To our knowledge, this is the first report of epinephrine and indomethacin combination efficacy in preventing PEP. According to our findings, we observed that the single application of epinephrine and the combination of epinephrine and indomethacin significantly reduced the risk of PEP $(p=0.016)$. The ERCP procedure might result in local or systemic inflammatory response, which is the precursor of PEP [32-34]. Furthermore, PLA2 has a vital role in the development of this inflammatory response [33]. It has been demonstrated that the mechanisms of NSAIDs in the prevention of PEP is to suppress peculiar molecular pathways that contributed to prostaglandin synthesis, PLA2, and neutrophil-endothelial cell attachment [33]. Indomethacin as an important inhibitor of PLA2 and its role in the prevention of PEP has been evaluated in several previous studies $[7,18,19,27]$. In line with our study, Elmunzer et al. [35] evaluated the efficacy of rectal indomethacin on 602 patients who underwent ERCP. They observed that rectal indomethacin significantly decreased the PEP incidence and severity. Among 79 patients who developed pancreatitis, 27 (9.2\%) were in the indomethacin group. However, in our study, the majority of patients who developed pancreatitis (6/7) were in the indomethacin group, and in comparison to the application of indomethacin and epinephrine combination, patients were at high risk of developing PEP $(p=0.016)$. In contrast to our study, a meta-analysis by Yaghoobi et al. [19] showed that rectal administration of indomethacin significantly decreased the PEP risk to half in related patients. In another study on the Iranian population, Sotoudehmanesh et al. [7] reported that administration of rectal indomethacin reduced the risk of PEP $(p=0.01, \mathrm{RRR}=88 \%, \mathrm{ARR}=0.16$, NNT $=6)$. However, the recent study by 


\section{Case Reports in Gastroenterology}

Case Rep Gastroenterol 2018;12:125-136

DOI: $10.1159 / 000479494$

(c) 2018 The Author(s). Published by S. Karger AG, Basel www.karger.com/crg

Hatami et al.: Epinephrine in the Prevention of Post-Endoscopic Retrograde

Cholangiopancreatography Pancreatitis: A Preliminary Study

Döbrönte et al. [20] revealed no benefit in the rectal application of indomethacin in reducing the incidence of PEP. This is consistent with their previous findings on 228 patients who underwent ERCP [21]. In our study, we excluded patients who underwent the placement of a stent in order to get a precise effect of the medication after the ERCP. There have been numerous studies that evaluated the efficacy of pancreatic duct stent placement and the prevention of PEP [36-38]. However, pharmacological agents have several benefits over stents including the cost benefit, ease of administration, minimal side effects, and widespread availability. Thus, despite the high efficacy of pancreatic stenting placement, it is not performed widely and one fifth of specialists prefer not to place pancreatic stents in any condition [39]. On the other hand, in an ad hoc analysis, Elmunzer et al. [40] showed that rectal indomethacin could replace PD stent placement in high-risk cases and a meta-analysis by Puig et al. [27] revealed that NSAIDs were effective either in the absence or presence of a pancreatic stent. The topical application of epinephrine and its role in the prevention of PEP has also been evaluated in several previous studies [5, 41, 42]. Matsushita et al. [5] observed that among 370 patients undergoing diagnostic ERCP, PEP developed in 4 cases $(1.1 \%)$ in the control group, whereas no PEP occurred in the epinephrine group $(0 / 185)(p=0.1230)$; they found that epinephrine sprayed on the papilla tended to reduce PEP; however, it was not statistically significant. One of the vital roles of epinephrine is the ability to decline edema and pancreatic ductal outflow obstruction, which is associated with the pathogenesis and progression of PEP [1-4]. In another valuable study, Xu et al. [42] evaluated the efficacy of epinephrine in a series of 461 patients and observed that PEP occurred in 9/461 individuals (6.45\%); however, the incidence rate was higher in the control group (31/480, 1.95\%). Therefore, applying epinephrine was a promising approach and reduced the incidence of pancreatitis after ERCP $(p=0.0086)$. A valuable meta-analysis by Akshintala et al. [41] evaluated the efficacy of several pharmacological agents for the prevention of PEP including NSAIDs, topical epinephrine, antibiotics, and nafamostat. They observed that in comparison to other agents, topical epinephrine had the most effect on reducing PEP with $85.9 \%$ followed by rectal NSAIDs with $58.1 \%$. In the present study, there were some limitations: first, the patients included in this study were recruited from a single center; however, a multiinstitutional registry is required to confirm our findings on combination efficacy of epinephrine and indomethacin. Second, due to our small sample size, we could not evaluate the effect of the putative medications on the severity of PEP in our patients.

\section{Conclusion}

In comparison to the administration of indomethacin alone, the combination of epinephrine and indomethacin seems to be effective in reducing PEP. A further randomized clinical trial with a larger sample size is required to confirm the efficacy of our medication in the prevention of pancreatitis after ERCP. 


\section{Case Reports in Gastroenterology}

\section{Acknowledgements}

This study was accomplished by grant No. 744 from Shahid Beheshti University of Medical Sciences, Tehran, Iran. We thank all patients and their families who participated in this study.

\section{Statement of Ethics}

Informed consent was obtained from all individuals and the research proposal was approved by the ethics committee of the Gastroenterology and Liver Diseases Research Center, Research Institute for Gastroenterology and Liver Diseases, Shahid Beheshti University of Medical Sciences, Tehran, Iran.

\section{Disclosure Statement}

The authors declare no conflicts of interest.

\section{References}

1 Andriulli A, Loperfido S, Napolitano G, Niro G, Valvano MR, Spirito F et al. Incidence rates of post-ERCP complications: a systematic survey of prospective studies. Am J Gastroenterol. 2007 Aug;102(8):1781-8.

2 Wang P, Li ZS, Liu F, Ren X, Lu NH, Fan ZN et al. Risk factors for ERCP-related complications: a prospective multicenter study. Am J Gastroenterol. 2009 Jan;104(1):31-40.

3 Zhou W, Li Y, Zhang Q, Li X, Meng W, Zhang L et al. Risk factors for postendoscopic retrograde cholangiopancreatography pancreatitis: a retrospective analysis of 7,168 cases. Pancreatology. 2011;11(4):399-405.

4 Lerch MM, Gorelick FS. Models of acute and chronic pancreatitis. Gastroenterology. 2013 Jun;144(6):118093.

5 Matsushita M, Takakuwa H, Shimeno N, Uchida K, Nishio A, Okazaki K. Epinephrine sprayed on the papilla for prevention of post-ERCP pancreatitis. J Gastroenterol. 2009;44(1):71-5.

6 Tarnasky P, Cunningham J, Cotton P, Hoffman B, Palesch Y, Freeman J et al. Pancreatic sphincter hypertension increases the risk of post-ERCP pancreatitis. Endoscopy. 1997 May;29(4):252-7.

7 Sotoudehmanesh R, Khatibian M, Kolahdoozan S, Ainechi S, Malboosbaf R, Nouraie M. Indomethacin may reduce the incidence and severity of acute pancreatitis after ERCP. Am J Gastroenterol. 2007 May;102(5):978-83.

8 Khoshbaten M, Khorram H, Madad L, Ehsani Ardakani MJ, Farzin H, Zali MR. Role of diclofenac in reducing post-endoscopic retrograde cholangiopancreatography pancreatitis. J Gastroenterol Hepatol. 2008 Jul;23(7 Pt 2):e11-6.

9 Balmadrid B, Kozarek R. Prevention and management of adverse events of endoscopic retrograde cholangiopancreatography. Gastrointest Endosc Clin N Am. 2013 Apr;23(2):385-403.

10 Yoo KS, Huh KR, Kim YJ, Kim KO, Park CH, Hahn T et al. Nafamostat mesilate for prevention of postendoscopic retrograde cholangiopancreatography pancreatitis: a prospective, randomized, double-blind, controlled trial. Pancreas. 2011 Mar;40(2):181-6.

11 Manes G, Ardizzone S, Lombardi G, Uomo G, Pieramico O, Porro GB. Efficacy of postprocedure administration of gabexate mesylate in the prevention of post-ERCP pancreatitis: a randomized, controlled, multicenter study. Gastrointest Endosc. 2007 Jun;65(7):982-7.

12 Yoo YW, Cha SW, Kim A, Na SY, Lee YW, Kim SH et al. The use of gabexate mesylate and ulinastatin for the prevention of post-endoscopic retrograde cholangiopancreatography pancreatitis. Gut Liver. 2012 Apr;6(2):256-61. 
13 Prat F, Amaris J, Ducot B, Bocquentin M, Fritsch J, Choury AD et al. Nifedipine for prevention of post-ERCP pancreatitis: a prospective, double-blind randomized study. Gastrointest Endosc. 2002 Aug;56(2):202-8.

14 Schwartz JJ, Lew RJ, Ahmad NA, Shah JN, Ginsberg GG, Kochman ML et al. The effect of lidocaine sprayed on the major duodenal papilla on the frequency of post-ERCP pancreatitis. Gastrointest Endosc. 2004 Feb;59(2):179-84.

15 Xu LH, Qian JB, Gu LG, Qiu JW, Ge ZM, Lu F et al. Prevention of post-endoscopic retrograde cholangiopancreatography pancreatitis by epinephrine sprayed on the papilla. J Gastroenterol Hepatol. 2011 Jul;26(7):1139-44.

16 Shao LM, Chen QY, Chen MY, Cai JT. Nitroglycerin in the prevention of post-ERCP pancreatitis: a metaanalysis. Dig Dis Sci. 2010 Jan;55(1):1-7.

17 Coelle EF, Adham N, Elashoff J, Lewin K, Taylor IL. Effects of prostaglandin and indomethacin on dietinduced acute pancreatitis in mice. Gastroenterology. 1983 Dec;85(6):1307-12.

18 Shi N, Deng L, Altaf K, Huang W, Xue P, Xia Q. Rectal indomethacin for the prevention of post-ERCP pancreatitis: A meta-analysis of randomized controlled trials. Turk J Gastroenterol. 2015 May;26(3):236-40.

19 Yaghoobi M, Rolland S, Waschke KA, McNabb-Baltar J, Martel M, Bijarchi R et al. Meta-analysis: rectal indomethacin for the prevention of post-ERCP pancreatitis. Aliment Pharmacol Ther. 2013 Nov;38(9):9951001

20 Döbrönte Z, Szepes Z, Izbéki F, Gervain J, Lakatos L, Pécsi G et al. Is rectal indomethacin effective in preventing of post-endoscopic retrograde cholangiopancreatography pancreatitis? World J Gastroenterol. 2014 Aug;20(29):10151-7.

21 Döbrönte Z, Toldy E, Márk L, Sarang K, Lakner L. Effects of rectal indomethacin in the prevention of postERCP acute pancreatitis. Orv Hetil. 2012 Jun;153(25):990-6.

22 van Ooijen B, Ouwendijk RJ, Kort WJ, Zijlstra FJ, Vincent JE, Wilson JH et al. Raised plasma thromboxane B2 levels in experimental acute necrotizing pancreatitis in rats. The effects of flunarizine, dazoxiben, and indomethacin. Scand J Gastroenterol. 1988 Mar;23(2):188-92.

23 Akshintala VS, Hutfless SM, Colantuoni E, Kim KJ, Khashab MA, Li T et al. Systematic review with network meta-analysis: pharmacological prophylaxis against post-ERCP pancreatitis. Aliment Pharmacol Ther. 2013 Dec;38(11-12):1325-37.

24 Dumonceau JM, Andriulli A, Deviere J, Mariani A, Rigaux J, Baron TH et al; European Society of Gastrointestinal Endoscopy. European Society of Gastrointestinal Endoscopy (ESGE) Guideline: prophylaxis of post-ERCP pancreatitis. Endoscopy. 2010 Jun;42(6):503-15.

25 Cotton PB, Lehman G, Vennes J, Geenen JE, Russell RC, Meyers WC et al. Endoscopic sphincterotomy complications and their management: an attempt at consensus. Gastrointest Endosc. 1991 May-Jun; 37(3):383-93.

26 Wildenhain PM, Melhem MF, Birsic WI, Sell HW, Rao KN. Acute hemorrhagic pancreatitis in mice: improved survival after indomethacin administration. Digestion. 1989;44(1):41-51.

27 Puig I, Calvet X, Baylina M, Isava Á, Sort P, Llaó J et al. How and when should NSAIDs be used for preventing post-ERCP pancreatitis? A systematic review and meta-analysis. PLoS One. 2014 Mar;9(3):e92922.

28 Robert A, Lum JT, Lancaster C, Olafsson AS, Kolbasa KP, Nezamis JE. Prevention by prostaglandins of caerulein-induced pancreatitis in rats. Lab Invest. 1989 May;60(5):677-91.

29 Katsinelos P, Fasoulas K, Paroutoglou G, Chatzimavroudis G, Beltsis A, Terzoudis S et al. Combination of diclofenac plus somatostatin in the prevention of post-ERCP pancreatitis: a randomized, double-blind, placebo-controlled trial. Endoscopy. 2012 Jan;44(1):53-9.

30 Sotoudehmanesh R, Eloubeidi MA, Asgari AA, Farsinejad M, Khatibian M. A randomized trial of rectal indomethacin and sublingual nitrates to prevent post-ERCP pancreatitis. Am J Gastroenterol. 2014 Jun;109(6):903-9.

31 Elmunzer BJ, Higgins PD, Saini SD, Scheiman JM, Parker RA, Chak A et al; United States Cooperative for Outcomes Research in Endoscopy. Does rectal indomethacin eliminate the need for prophylactic pancreatic stent placement in patients undergoing high-risk ERCP? Post hoc efficacy and cost-benefit analyses using prospective clinical trial data. Am J Gastroenterol. 2013 Mar;108(3):410-5.

32 Karne S, Gorelick FS. Etiopathogenesis of acute pancreatitis. Surg Clin North Am. 1999 Aug;79(4):699-710.

33 Gross V, Leser HG, Heinisch A, Schölmerich J. Inflammatory mediators and cytokines - new aspects of the pathophysiology and assessment of severity of acute pancreatitis? Hepatogastroenterology. 1993 Dec; 40(6):522-30.

34 Bhatia M, Brady M, Shokuhi S, Christmas S, Neoptolemos JP, Slavin J. Inflammatory mediators in acute pancreatitis. J Pathol. 2000 Feb;190(2):117-25. 


\section{Case Reports in Gastroenterology}

Hatami et al.: Epinephrine in the Prevention of Post-Endoscopic Retrograde

Cholangiopancreatography Pancreatitis: A Preliminary Study

35 Elmunzer BJ, Scheiman JM, Lehman GA, Chak A, Mosler P, Higgins PD et al; U.S. Cooperative for Outcomes Research in Endoscopy (USCORE). A randomized trial of rectal indomethacin to prevent post-ERCP pancreatitis. N Engl J Med. 2012 Apr;366(15):1414-22.

36 Choudhary A, Bechtold ML, Arif M, Szary NM, Puli SR, Othman MO et al. Pancreatic stents for prophylaxis against post-ERCP pancreatitis: a meta-analysis and systematic review. Gastrointest Endosc. 2011 Feb;73(2):275-82.

37 Mazaki T, Mado K, Masuda H, Shiono M. Prophylactic pancreatic stent placement and post-ERCP pancreatitis: an updated meta-analysis. J Gastroenterol. 2014 Feb;49(2):343-55.

38 Freeman ML, Overby C, Qi D. Pancreatic stent insertion: consequences of failure and results of a modified technique to maximize success. Gastrointest Endosc. 2004 Jan;59(1):8-14.

39 Dumonceau JM, Rigaux J, Kahaleh M, Gomez CM, Vandermeeren A, Deviere J. Prophylaxis of post-ERCP pancreatitis: a practice survey. Gastrointest Endosc. 2010;71:934-9, 939.e1-2.

40 Elmunzer BJ, Higgins PD, Saini SD, Scheiman JM, Parker RA, Chak A et al; United States Cooperative for Outcomes Research in Endoscopy. Does rectal indomethacin eliminate the need for prophylactic pancreatic stent placement in patients undergoing high-risk ERCP? Post hoc efficacy and cost-benefit analyses using prospective clinical trial data. Am J Gastroenterol. 2013 Mar;108(3):410-5.

41 Akshintala VS, Hutfless SM, Colantuoni E, Kim KJ, Khashab MA, Li T et al. Systematic review with network meta-analysis: pharmacological prophylaxis against post-ERCP pancreatitis. Aliment Pharmacol Ther. 2013 Dec;38(11-12):1325-37.

42 Xu LH, Qian JB, Gu LG, Qiu JW, Ge ZM, Lu F et al. Prevention of post-endoscopic retrograde cholangiopancreatography pancreatitis by epinephrine sprayed on the papilla. J Gastroenterol Hepatol. 2011 Jul;26(7):1139-44. 


\section{Case Reports in Gastroenterology}

Case Rep Gastroenterol 2018;12:125-136

\begin{tabular}{l|l}
\hline DOI: 10.1159/000479494 & (c 2018 The Author(s). Published by S. Karger AG, Basel \\
\hline
\end{tabular} www.karger.com/crg

Hatami et al:: Epinephrine in the Prevention of Post-Endoscopic Retrograde

Cholangiopancreatography Pancreatitis: A Preliminary Study

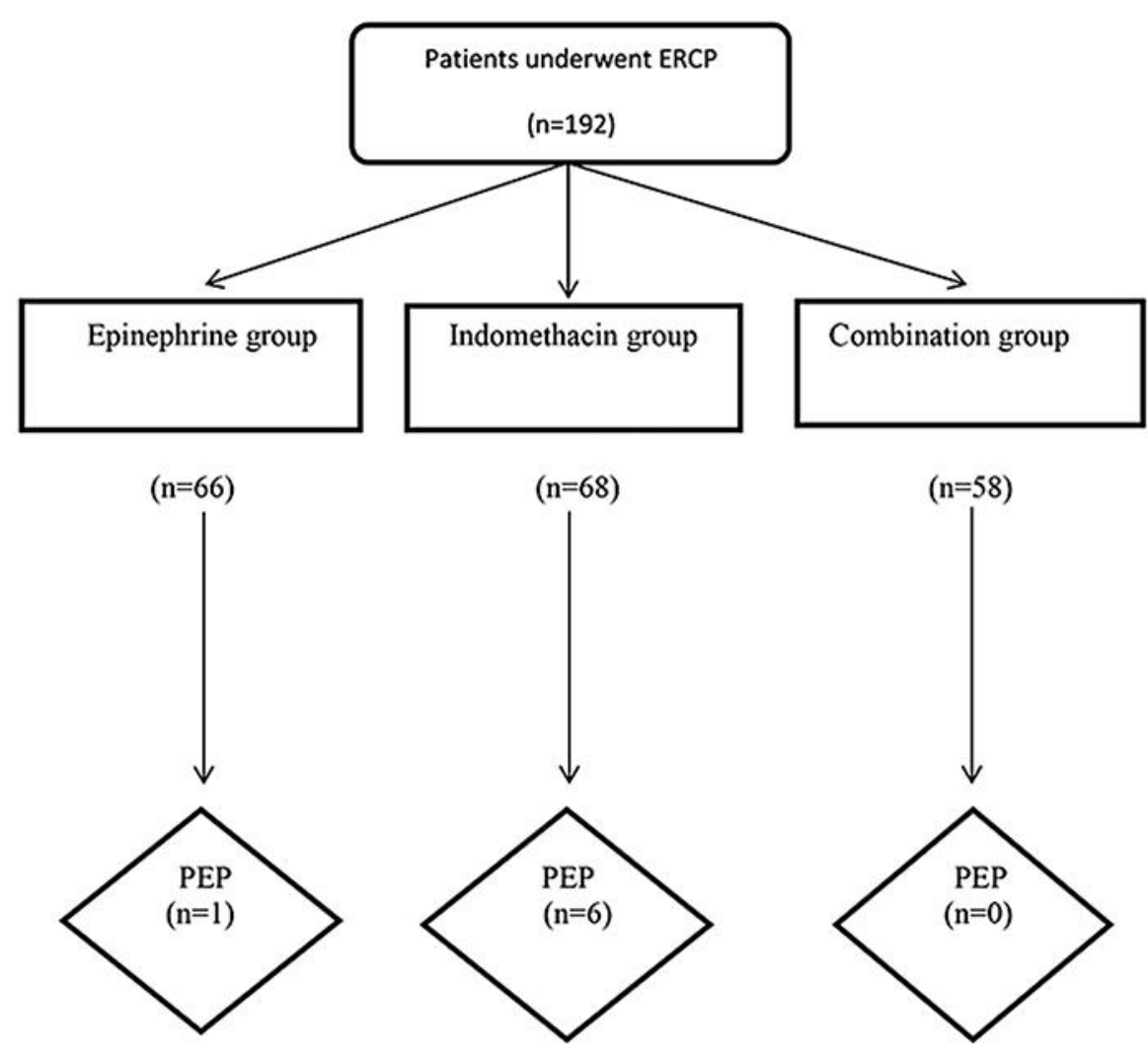

Fig. 1. Flowchart of patients through the clinical protocol. PEP, post-endoscopic retrograde cholangiopancreatography pancreatitis. 


\section{Case Reports in Gastroenterology}

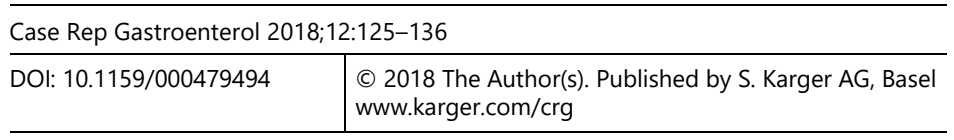

Hatami et al.: Epinephrine in the Prevention of Post-Endoscopic Retrograde Cholangiopancreatography Pancreatitis: A Preliminary Study

Table 1. Demographic and clinical characteristics of patients undergoing ERCP

\begin{tabular}{lccrc}
\hline & Epinephrine & Indomethacin & Combination & $p$ \\
& $n(\%)$ & $n(\%)$ & $n(\%)$ & value \\
\hline Male & $33(33.7)$ & $41(41.8)$ & $24(24.5)$ & 0.104 \\
Female & $33(35.1)$ & $27(28.7)$ & $34(36.2)$ & 0.818 \\
Mean age, years & $59.59 \pm 15.680$ & $58.06 \pm 17.125$ & $59.62 \pm 15.369$ & 0.404 \\
PD dilation & $1(12.5)$ & $4(50.7)$ & $3(37.5)$ & 0.970 \\
CBD stone & $28(34.1)$ & $30(36.6)$ & $24(29.3)$ & 0.687 \\
PD injection & $2(33.3)$ & $3(50.0)$ & $1(16.7)$ & 0.329 \\
PD cannulation & $6(50.0)$ & $2(16.7)$ & $4(33.3)$ & 0.343 \\
CBD dilation & $48(37.5)$ & $45(35.2)$ & $35(27.3)$ & 0.533 \\
Balloon dilation of sphincter of Oddi & $16(42.1)$ & $12(31.6)$ & $9(26.3)$ & 0.712 \\
Biliary stricture & $13(40.6)$ & $10(31.2)$ & $6(37.5)$ & 0.389 \\
Biliary duct tumor & $3(18.8)$ & $7(43.8)$ & $3(37.5)$ & 0.808 \\
Suspected SOD & $3(37.5)$ & $2(25.0)$ & $23(41.1)$ & 0.076 \\
Difficult cannulation & $14(25.0)$ & $19(33.9)$ & $50(32.5)$ & 0.421 \\
Sphincterotomy & $51(33.1)$ & $53(34.4)$ & $9(39.1)$ & 0.610 \\
Needle knife precut & $7(30.4)$ & $7(30.4)$ & $16(32.7)$ & 0.872 \\
Peri-ampullary diverticulum & $17(34.7)$ & $16(32.7)$ & $12(31.6)$ & 0.976 \\
Cholecystectomy & $13(34.2)$ & $13(34.2)$ & $96(45.62)$ & 0.732 \\
Pre-amylase level, IU/L & $88.4(40.25)$ & $98(43.2)$ & $90.1(41.85)$ & 0.605 \\
Pre-lipase level, IU/L & $101(51.40)$ & $92.5(46.9)$ & $269.1(257.6)$ & 0.460 \\
Post-amylase level (4 h), IU/L & $264.5(255.1)$ & $286.3(274.5)$ & $615.4(1,064.2)$ & 0.542 \\
Post-amylase level (24 h), IU/L & $642.1(1,115)$ & $676(1,163.3)$ & \\
\hline
\end{tabular}

ERCP, endoscopic retrograde cholangiopancreatography; PD, pancreatic duct; CBD, common bile duct; SOD, sphincter of Oddi dysfunction.

Table 2. Outcomes of patients after endoscopic retrograde cholangiopancreatography

\begin{tabular}{lllll}
\hline & $\begin{array}{l}\text { Epinephrine } \\
n(\%)\end{array}$ & $\begin{array}{l}\text { Indomethacin } \\
n(\%)\end{array}$ & $\begin{array}{l}\text { Combination } \\
n(\%)\end{array}$ & $\begin{array}{l}p \\
\text { value }\end{array}$ \\
\hline $\begin{array}{llll}\text { Pancreatitis } \\
\text { Mild }\end{array}$ & $1(20)$ & $4(80)$ & $0(0.0)$ & 0.016 \\
Moderate & $0(0.0)$ & $1(100)$ & $0(0.0)$ & \\
Severe & $0(0.0)$ & $1(100)$ & $0(0.0)$ & \\
\hline
\end{tabular}


Hatami et al.: Epinephrine in the Prevention of Post-Endoscopic Retrograde Cholangiopancreatography Pancreatitis: A Preliminary Study

Table 3. Univariate analysis of risk factors for post-ERCP pancreatitis in patients with and without pancreatitis

\begin{tabular}{lclcc}
\hline & $\begin{array}{c}\text { Non-pancreatitis } \\
\text { group, } n(\%)\end{array}$ & $\begin{array}{l}\text { Pancreatitis } \\
\text { group, } n(\%)\end{array}$ & $\begin{array}{l}\text { Total (n= 704) } \\
n(\%)\end{array}$ & $p$ value \\
\hline PD dilation & $8(100)$ & $0(0)$ & $8(100)$ & 0.739 \\
Suspected SOD & $8(100)$ & $0(0)$ & $8(100)$ & 0.739 \\
Cholecystectomy & $37(97.4)$ & $1(2.6)$ & $38(100)$ & 0.581 \\
CBD stone & $80(97.6)$ & $2(2.4)$ & $82(100)$ & 0.355 \\
Difficult cannulation & $130(95.6)$ & $6(4.4)$ & $136(100)$ & 0.343 \\
Sphincterotomy & $150(97.4)$ & $4(2.6)$ & $154(100)$ & 0.134 \\
Needle knife precut & $23(100)$ & $0(0.0)$ & $23(100)$ & 0.403 \\
PD cannulation & $11(91.7)$ & $1(8.3)$ & $12(100)$ & 0.368 \\
PD injection & $6(100)$ & $0(0)$ & $6(100)$ & 0.798 \\
Balloon dilation of sphincter of Oddi & $36(94.7)$ & $2(5.3)$ & $38(100)$ & 0.419 \\
CBD dialation & $123(95.4)$ & $5(4.6)$ & $128(100)$ & 0.571 \\
Biliary stricture & $30(93.8)$ & $2(6.2)$ & $32(100)$ & 0.330 \\
Biliary duct tumor & $15(93.8)$ & $1(6.2)$ & $14(100)$ & 0.462 \\
Peri-ampullary diverticulum & $47(95.9)$ & $2(4.1)$ & $49(100)$ & 0.571 \\
Medication & & & & \\
$\quad$ Epinephrine & $66(100)$ & $0(0.0)$ & $66(100)$ & 0.016 \\
$\quad$ Indomethacin & $62(91.2)$ & $6(8.8)$ & $68(100)$ & \\
$\quad$ Combination & $57(98.3)$ & $1(1.7)$ & $58(100)$ & \\
\hline
\end{tabular}

ERCP, endoscopic retrograde cholangiopancreatography; PD, pancreatic duct; CBD, common bile duct; SOD, sphincter of Oddi dysfunction. 